\title{
HISTORIA NAJNOWSZA - POMIĘDZY PEWNOŚCIA A ZWĄTPIENIEM?
}

Hubert ŁASZKIEWICZ

\section{ABSTRACT}

\section{CONTEMPORARY HISTORY - BETWEEN CERTAINTY AND DOUBT?}

The paper discuss the regulatory principles which might be included into discussion on the controversy over the uses and misuses of contemporary history in Poland. The main proposals are as follow. We need greater methodological awareness that sources we are using whilst describing and interpreting the history are not reflecting the whole past (which is simply impossible). While observing divergent versions of reconstructed past one should notice that the most divergent matters are connected with ethics. Three levels of ethics and moral judgments are listed: professional ethic of historian (is he a judge or observer), ethics/moral judgments of the past we investigate, moral judgment about the past. However tempting, metaphorical use of language should be limited at least at this stage of controversy, for there are not a commonly agreed set of metaphors, thus their use might only complicate the exchange of opinions.

\section{KEYWORDS:}

Sources analysis, professional ethics of historian, moral judgments in history, methodology of history, methodology of social sciences, historical synthesis, 
Is all that we see or seem

But a dream within a dream?

Edgar Allen Poe, A Dream Within a Dream

Nie mów: jak to jest,

$\dot{z} e$ dni dawne byty lepsze niż te, co sa teraz?

Bo nie z mądrości zapytujesz o to.

Eklezjasta, 7, 10, przekład Czesława Miłosza

Wypowiedź Profesora Jana Pomorskiego porusza wiele wątków ważnych nie tylko dla historyka dziejów najnowszych. $\mathrm{Z}$ tych najważniejszych wymienić należy pewność i rzetelność poznania historycznego i jego przedstawienia tak, aby oddawało sprawiedliwość (rzetelny osąd) osobom działającym - podmiotom dziejów. Nie sposób się z tym nie zgodzić. Jednak na tej drodze historyk napotyka na różnorakie przeszkody: wynikające z własnego zaangażowania politycznego i społecznego, niemniej z tego, że nie wszyscy podzielają te same przekonania religijne, filozoficzne, metodologiczne i, co nie jest bez znaczenia, nie wszyscy w poznaniu historycznym stawiają sobie te same cele i adresują wyniki swojej pracy do tego samego odbiorcy. Poza tym historyk jest istotą organiczną i jego fizjologia (patrz: uwagi J. Pomorskiego w kontekście neuronauki o pracy mózgu, pamiętaniu i zapominaniu) kształtuje zdolności percepcyjne i ogólnie poznawcze. Jest jeszcze jeden problem, z którym każdy badacz musi sobie poradzić: posługiwanie się językiem opisu, który będzie zrozumiały dla jak najszerszego kręgu czytelników. Mamy więc do czynienia z różnymi światami (nadawców i odbiorców), które, aby zachować możliwość komunikacji i dyskutowania, należy w określony sposób połączyć. Tym łącznikiem mają być intersubiektywnie zrozumiałe zasady metodologiczne, inspirowane przez współczesną neuroscience i, z drugiej strony, reguły etyki obywatelskiej (patrz: budowanie kapitału społecznego), a wreszcie zwykłe zasady uczciwości: nie kłamię, nie krzywdzę, jeżeli nie posiadam dowodu (uznanego za taki w świetle przyjętych zasad warsztatowych) nie wygłaszam sądów stanowczych i ostatecznych - in dubio pro reo.

Badanie współczesności i nieodległej przeszłości musi powodować spory, jego rezultaty są odmienne, ale chodzi o to, aby różnice w interpretacjach i wyjaśnieniach były uprawnione, to znaczy zgodne z przyjętymi w środowisku badaczy regułami; spór 
jest rzeczą naturalną i oczywistą, zawsze towarzyszącą nauce'. Kłótnia i wykluczenie sprzeciwiają się ideałowi nauki, w którym argument znaczyć ma więcej niż siła przekonania i wiary, a przeciwnik nie jest wrogiem, ale drugą stroną dyskusji. Niezwykle cenną umiejętnością jest sztuka dystansu wobec własnych wytworów intelektualnych; zmniejszając „temperaturę” debaty, uzyskujemy jej pogłębienie i poszerzenie².

\section{POTĘGA METAFORY I ANALOGII ORAZ JE] (CZASAMI) KŁOPOTLIWE SKUTKI}

W jednej ze scen filmu Petera Weira, Piknik pod Wiszaca Skała (1975), słyszymy słowa z wiersza Edgara Allena Poe A Dream Within a Dream:

All that we see or seem

Is but a dream within a dream

Wszystko co widzimy i co nam się zdaje jest tylko snem we śnie. A więc nie mamy żadnej pewności, że to co postrzegamy, widzimy (wiemy o tym, rozumiemy to) naprawdę. Film dzieje się w Australii. W dzień św. Walentego, 14 lutego roku 1900, w sobotę, cztery uczennice ze szkoły w Appleyard odłączają się od koleżanek i razem z jedną z nauczycielek wędrują na górę zwaną Wiszącą Skałą. Po kilku dniach powraca tylko jedna. Pozostałe wraz z nauczycielką znikają bez śladu. Mimo poszukiwań nikt ich nie odnalazł i nie ustalono, co się z nimi stało. A wszystko to pomimo świadków zdarzenia, poszukiwań z psami i tropicielami. Następnie zaś historyk napotyka na problem podstawowy: opisanie, możliwe pełne i możliwie, danego zdarzenia. Aby to zrobić posługuje się świadectwami, których wiarygodność ocenia i interpretuje. Krytycyzm wobec źródeł i historiografii, niemniej namysł metodologiczny mogą sprawić, że badacz ma więcej wątpliwości niż pewności. Scio me nihil scire nie jest przecież tylko samowiedzą filozofa, jest też uprawnioną wątpliwością historyka.

Metodyczne wątpienie może prowadzić do paradoksalnego stwierdzenia, że wiele $\mathrm{z}$ tego, co piszemy o wydarzeniach minionych i nam współczesnych jest w zasadzie „snem we śnie”. Im mniejszy dystans czasowy od opisywanych i interpretowanych zdarzeń i procesów, im mniejsza możliwość weryfikacji opisu zdarzeń, tym mniejsza pewność, że opis nasz (i nasza wiedza o zdarzeniu) jest adekwatny. Tę niepewność oddajemy - my historycy - przez metafory i analogie (paralele), po które sięgamy do

\footnotetext{
Czasami nawet najgłośniejsze sprawy polityczne nie znajdują wyjaśnienia, zarówno współcześnie przed sądem, jak też po latach przez historyków. To powinno być przestrogą przed złudną pewnością wiedzy kompletnej. Por.: M. Żuławnik, Eksplozja w Cytadeli 13 października 1923 r. Przyczynek do działalności komunistów w Garnizonie Warszawa, w: Komuniści w międzywojennej Warszawie, pod redakcją Elżbiety Kowalczyk, Warszawa, 2014, s. 151-174.

2 Por.: rozważania ważne, aczkolwiek w formie pastiszu tekstu naukowego: Śledź Otrembus Podgrobelski, Wstęp do imagineskopii (próba zarysu), Pruszków 2009.
} 
nauk pokrewnych (lub bardzo odległych) albo też do sztuk plastycznych, obrazów literackich, czy też innych dziedzin sąsiednich, realizowanych, jak nam się wydaje, z pełniejszą gwarancją heurystyczną i metodologiczną. W tym miejscu jednak nasze rozumowanie trafia na problem, który ma dwa wymiary. Po pierwsze, nawet nauki z dziedzin przyrodniczych wcale nie dysponują większą pewnością niż nasza; współcześni biolodzy powiedzą, że ich wiedza jest p r a w d o p o d o b n a. Po drugie, a to chyba ważniejsze, nie wszyscy historycy uprawiają refleksję na temat własnego poznania: jego założeń, kompletności i systematyczności. Wreszcie nie wszyscy z nas uważają, że zdanie wypowiedziane przez Michela de Certeau (historia nigdy nie jest pewna) ma głębszy sens. Dla dobra dyskusji o dziejach najnowszych warto więc na pewien czas zrezygnować z paraleli, które w technice retorycznej (i dla wyobraźni historycznej) mają swoje znaczenie, ale mogą powiększyć tylko odległość pomiędzy dyskutantami ${ }^{3}$. Ponadto, nie wszyscy historycy dziejów najnowszych podzielają przekonanie o potrzebie korzystania $z$, rozszerzonej o rozmaite kulturowe paralele, refleksji metodologicznej; tym bardziej warto skłaniać ich do konsekwentnego namysłu nad obecnymi praktykami badania historycznego (przynajmniej tymi, które sami realizują). Zdaję sobie przy tym sprawę z tego, że ucieczki od metaforyki dokonać się nie da, bo taki jest charakter języka naturalnego i nieliniowa struktura myślenia skojarzeniowego, którymi się posługujemy. Dlatego poszukiwanie tzw. języka nauki i w konsekwencji jego formalizacja (np. wedle wzorów logiki i matematyki) jest w naszej dziedzinie niecelowa i niestosowna. Z kolei to, że w poznaniu historii pomocne są empiryczne badania nad mózgiem, psychologia, ekonomia, antropologia kulturowa itp. jest zrozumiałe dla mnie, ale być może nie jest oczywiste dla koreferentów. Niemniej zakładam, że jakaś forma heurystycznych principiów będzie nam dzisiaj potrzebna, bo inaczej zabraknie płaszczyzny dyskursywnego spotkania.

\section{KUMULACYJNY I KONCEPTUALNY GMACH WIEDZY O DZIE- JACH NAJNOWSZYCH}

Ujmując rzecz bardzo ogólnie mamy taką sytuację. W kumulacyjnym gmachu wiedzy należy przebadać próbę reprezentatywną (lub nawet wszystkie) spółdzielni

3 Jeżeli bowiem kogoś film Piknik pod Wiszącą Skatą nie zachwyca, a to jest możliwe i uprawnione, to także nie zachwyci go Moniza Clavier Sławomira Mrożka (z pięknym literackim obrazem mitologizacji historii własnej Polski), a nawet nie zachwyci go źródło sformułowania „nie zachwyca” - czyli Ferdydurke Witolda Gombrowicza. Aczkolwiek do metafor (i analogii) czerpanych z księgi naszej kultury, zaliczyłbym też koncepcje metodologiczne, te najwyższego rzędu, które proponują porządkowanie chaosu świadectw o przeszłości wedle pewnego porządku sądzę, że Giorgio Agamben nie zachwyca, a nawet Franz Fanon też nie. Skoro nie zachwyca, to skupmy się na tym, co musi być wzięte pod uwagę: w pierwszym rzędzie na źródłach i ich interpretacjach. 
mieszkaniowych, szkół podstawowych, dokumentów KC, i innych podmiotów i przedmiotów dziejów najnowszych, aby stworzyć syntezę. W konceptualnym gmachu wiedzy zadowalający rezultat (zrozumienie) wynika z zastosowania, sformułowania i dowiedzenia na podstawie pewnej koncepcji metodologicznej (syntetyzującej), że dzieje można w określony przez nas sposób interpretować. Obydwa gmachy (potęga metafory!) stoją jednak obok siebie i chyba czasem jeden na drugim się silnie wspiera, a kiedy wali się jeden, drugi zyskuje materiał do odbudowy i odwrotnie. Czy jest tak, jak mówi Dariusz Stola, cytowany w tekście Jana Pomorskiego, że pomimo narastania wiedzy szczegółowej, coraz mniej wiemy o PRL-u? Sądzę, że nie. Wiedza szczegółowa, o ile rzetelnie przytoczona, daje nam możliwość tworzenia gmachu konceptualizacji i to bardzo dużą, ponieważ dzieło uniezależnia się od twórcy. Inna sprawa to doskonalenie umiejętności czytania i interpretowania danych, bo tej czasami może brakować.

Kumulacja i konceptualizacja są ze sobą ściśle powiązane - charakter tych związków nie opiera się jednak o prawo mówiące, że ilość przechodzi w jakość. Ten związek jest o wiele bardziej złożony i nielinearny. Uważam, że dyskusja na ten temat podjęta przede wszystkim z socjologami, ekonomistami i psychologami byłaby dla historyków dziejów najnowszych bardzo pożyteczna. W jej ramach jedno zagadnienie wysunąłbym na plan pierwszy: sprawczość i intencjonalność podmiotu działającego (czyli człowieka), w tym kwestia: jak podlega on procesom społecznym, które tworzy i w których uczestniczy. Dyscypliny nauk społecznych pozwalają spojrzeć na działalność człowieka w dziejach z mniejszym naciskiem na jego intencjonalność i sprawczość - ta jest natomiast ośrodkiem większego zainteresowania historyków. Nie ma w tym przeciwieństwa, a więc praktyka badawcza historyka, ekonomisty i socjologa nie są aż tak od siebie odmienne. Ważne jest, aby nie tracąc z oczu metod pracy i interpretacji własnej dyscypliny wzbogacać je o osiągnięcia innych dyscyplin. W wypadku nauk społecznych mamy też do czynienia z większą koncentracją na konceptualizacji badań, większą świadomością tymczasowości dokonanych ustaleń (ważnych tu i teraz, dla określonej grupy badanej) oraz z lepszym wyposażeniem w metody ilościowe. Historyk dziejów najnowszych opracowując biografię osoby czy grupy, dzięki naukom społecznym będzie bardziej wrażliwy na procesy społeczne, które są wynikiem decyzji/zaniechania pojedynczych podmiotów działających, ale też stają się czasami niezależnie od tych podmiotów (w takim sensie, że sprawstwa w tych procesach nie da się łatwo powiązać z decyzjami poszczególnych osób, a więc konstruowanie takich związków może być efektem błędu metodologicznego albo nawet świadomym nadużyciem). 
Ludzka aktywność nie zawsze jest intencjonalna, a intencjonalność rzadko daje się określić w sposób jednoznaczny. Nie zaprzecza to racjonalności działania - zaprzecza jednak przekonaniu, że istnieje tylko jeden wzór racjonalności. Podobnie - nie ma też jednej propozycji syntezy historycznej. Może nią być książka Rémi Brague’a, Europe, la voie romaine ${ }^{4}$, a także Normana Daviesa, Europa. Rozprawa historyka z historia ${ }^{5}$.

\section{ŚWIAT PRZEDSTAWIONY W ŹRÓDŁACH A DZIANIE SIĘ}

Poznajemy przeszłość poprzez źródła. To stwierdzenie mało odkrywcze, ale medytacja nad nim powinna zawsze towarzyszyć historykowi, szczególnie historykowi dziejów najnowszych. Chodzi o to, że świat przedstawiony w źródłach (o bardzo różnej proweniencji, zróżnicowanych jak to tylko możliwe) nie jest światem samym. Przeszłość, czy też to, co nazywamy teraźniejszością, nie jest odwzorowana w źródłach - a na pewno nie znamy dystansu, różnicy, stopnia przekształcenia pomiędzy, żeby użyć terminu z dziedziny literaturoznawstwa, światem przedstawionym w źródłach, a tym światem, który czynimy przedmiotem swojego badania. Mówiąc najprościej: zapisy źródłowe nie są światem, który badamy, nie dają wglądu „bezpośredniego” w dzieje. Świadomość tego faktu ma poważne konsekwencje metodologiczne. Dobrze są one znane historykom na poziomie deklaracji na temat własnej pracy, stanowią podstawę edukacji na każdych studiach historycznych, ale w praktyce badawczej, szczególnie tam, gdzie historyka przytłacza nadmiar źródeł, są czasami zapominane. Badacz dziejów najnowszych dysponuje mnogością, która wcale nie ułatwia mu zadania.

\footnotetext{
Gallimard, Paris 1992.

Przekład: E.Tabakowska, Kraków 2007.

Użyłem słowa „dzianie się” zainspirowany historią walki o krzyż w Nowej Hucie, która się rozegrała w dniach 27-28 kwietnia 1960 roku. Została ona opisana przez krakowskiego reportera Jerzego Lovella (Reportaż o historii wspótczesnej. Twarz Ziemi, [w:] J. Lovell, Start do ziemi ludzkiej, Kraków 1964, s. 200-228). Kościół w miejscu krzyża wybudowano dopiero w 2001 roku. Zdarzenia opowiedziane przez Lovella są dokumentowane aktami milicyjnymi i sądowymi. Konkluzja i ocena jaką daje reporter jest przychylna decyzji władz PRL - a więc konflikt był niepotrzebny, bo więcej korzyści społecznych wynikło ze zbudowania w tym miejscu szkoły niż kościoła. Jednakże z tego reportażu, raczej tendencyjnego, warto przytoczyć dwie informacje. Jedna to refleksja nad pracą historyka: Przyszły historyk - jeśli $z$ wielości zdarzeń dobrych $i z ł y c h$, z prędkich i gwaltownych dziejów nam wspótczesnych zechce oddzielić $i$ wyodrębnić ten jeden moment wtaśnie, dzieje jednego dnia i nocy - będzie poszukiwał dokumentów, które konflikt zawęźlity, stworzyly jego przestanki (s. 204). A druga to zabieg kompozycyjny autora, aby wpleść do reportażu fragmenty donosów tajnych agentów z powieści o Bizancjum Teodora Parnickiego pt. Twarz księżyca. Opowieść bizantyńska z roku 450. Mamy dzięki temu dwustopniową narrację: dokumentów milicyjnych i sądowych oraz rozmów z ludźmi z jednej strony, z drugiej zaś cytaty z doniesień tajnych agentów z powieści Parnickiego. Zobiektywizowana narracja reportażysty jest, czy też taki był zamiar autora, wzięta w nawias przez listy tajnej policji „Bizancjum” - z epoki rzecz jasna odległej. Swoistą tu kodą jest to, że kościół jednak stanął po latach blisko przewidzianego dla niego w 1957 roku miejsca (wtedy wystawiono tam drewniany krzyż). Od momentu pisania reportażu (1962 r.) i jego wydania (1964 r.) historia krzyża i starań o kościół w Nowej Hucie kilkakrotnie doznała znaczących zwrotów. Póki więc dzieje się nie skończyły, ich interpretacja jest zawsze interpretacją związaną z czasem jej powstania.
} 
Skoro przedmiot badań jest nieodległy w czasie historyk z własnego doświadczenia wie, że wiele wypowiedzi, które wykorzystuje ma charakter stronniczy. Co więcej, wiele z dokumentów wytworzonych przez instytucje ma charakter zarówno niepełny i zwodniczy. Słowa, obrazy, liczby, daty, wskazanie winnych, odpowiedzialnych i wiele innych zagadnień, które w źródłach występują, nie mają charakteru czysto intencjonalnego przekazu o przeszłości dla przyszłych pokoleń. Są przekazem zakorzenionym w intencjonalności i zarazem przypadkowości/żywiołowości dziania się tu i teraz. I to zwłaszcza powinno się brać pod uwagę względem heurezy naszej dziedziny.

\section{JAKĄ HISTORIOGRAFIĘ POLACY MAJĄ?}

Odwracam pytanie Profesora Pomorskiego - bo Polacy potrzebują dobrej historiografii - to sąd najogólniejszy - ale skoro nie ma zgody, co w wypadku historiografii oznacza pojęcie „dobra historiografia”, to należy skupić się na analizie tego, co jest: analizie istniejących praktyk historiograficznych i zarysować ich typologię - części wspólne i rozbieżne. Wiele z tej pracy zostało już zrobione i można na tej podstawie powiedzieć, że w polskiej historiografii dziejów najnowszych da się wyróżnić następujące grupy prac badawczych (podział nie ma charakteru rozłącznego):

- Studium społeczeństwa polskiego: procesy społeczne, psychologia zbiorowa, pamięć, zachowania religijne, polityczne, społeczne, przemiany mentalne, etc.;

- Studium instytucji władzy: PPR - PZPR, innych partii, Milicji Obywatelskiej, LWP, innych instytucji;

- Studium instytucji niezależnych od władz PRL: głównie Kościoła rzymskokatolickiego - z silnym wątkiem afirmatywnym z jednej strony i dekonstrukcyjnym z drugiej;

- Studium osób (bohaterów i anty-bohaterów): w tym nurcie ważnym wątkiem jest dekonstrukcja lub afirmacja osób, które uznano kiedyś za bohaterów (anty-bohaterów);

- Studium niezależnych od władz PRL środowisk konspiracyjnych, politycznych i społecznych (w tym studenckich), religijnych; tym studiom przyświeca pytanie: kto rzeczywiście walczył z komunizmem i jaki był rzeczywisty wkład oporu społecznego w jego upadek. Jest też nurt rozliczeniowy, związany z konfliktami, które istniały już wcześniej w środowiskach niezależnych, a które pogłębiły się w czasie ponad dwudziestu lat niepodległości;

- Studium wszystkich innych aspektów dziejów. 
Z tej typologii (tymczasowej oczywiście) wynika, że w praktyce historiograficznej dziejów najnowszych ważnym wątkiem jest ocena moralna osób, instytucji, działań podejmowanych w nieodległej przeszłości. Wprost czy pośrednio dyskutowane są kwestie oddawania sprawiedliwości osobom i instytucjom, budowania pamięci zbiorowej, a przez to wychowywania współczesnych i przyszłych pokoleń obywateli Polski. Ambicją i zamiarem badaczy jest ustalenie i ocena postaw, szczególnie postaw oporu/współpracy z władzami PRL.

Spośród różnych czynników, które wpływają na postępowanie człowieka ważnym wątkiem tekstu Jana Pomorskiego jest zwrócenie uwagi na rolę emocji w procesach podejmowania decyzji i w mechanizmach zapamiętywania; te związane z ocenami moralnymi mają, jak się okazuje, największą siłę oddziaływania. Chodzi tu zarówno o badaczy przeszłości, jak też o odbiorców ich dzieł. Ten nurt ocen moralnych w historiografii dziejów najnowszych budzi najwięcej sporów w środowisku. Rozpoczynają się one na poziomie warsztatu, oceny wiarygodności ustaleń, dalej sądów syntetyzujących i wreszcie na poziomie składu zasad aksjologicznych, wedle których przeszłość ma być oceniana. Pytanie o to, czy historyk ma być sędzią czy też powstrzymać się powinien od wydawania wyroków, otrzymuje różne, przeciwstawne, odpowiedzi. Zgodzić się musimy, że początki historiografii krytycznej są związane także z zasadami stosowanymi w procedurze prawnej: ustalanie stanu faktycznego. W tym sensie historyk pełni także rolę prawnika, czyli jest sędzią. Czy ma być także sędzią wskazującym na winę/zasługę i orzekającym o karze/nagrodzie? Modernizacja nauki doprowadziła do usunięcia $\mathrm{z}$ repertuaru ocen ferowanych w nauce osądów moralnych. W niektórych, wcale licznych, tradycjach i szkołach historycznych taka właśnie postawa znalazła swoje prawo obywatelstwa. Jednocześnie jednak analiza praktyk historiograficznych wskazuje, że historycy stają się sędziami - a przynajmniej, pomimo wysiłku obiektywizacji, nie udaje im się tego uniknąć. Ważnym głosem w tej sprawie jest bardzo osobista książka Carlo Ginzburga, The Judge and the Historian ${ }^{7}$, która jednak nie wzbudziła w Polsce większego zainteresowania.

\section{PODSUMOWANIE}

Pewność poznania historycznego i jego rzetelność rywalizuje ze zwątpieniem, które towarzyszy każdej krytycznej refleksji na temat ważności i wiarygodności oraz statusu poznawczego osiągniętych rezultatów badawczych. Pogłębiona świadomość złożoności sposobów percepcji ludzkiej, którą postuluje Profesor Jan Pomorski

7 Marginal Notes on a Late-Twentieth-Century Miscarriage of Justice, London-New York, 2002. 
(patrz: sposób działania ludzkiego mózgu) jest na pewno ważnym czynnikiem rozwijającym samowiedzę historyka. To, jak działa nasz najważniejszy organ, dzięki któremu mamy wiedzę i dokonujemy operacji badawczych, warunkuje to, jak myślimy, zapamiętujemy, przetwarzamy, zapisujemy i odczytujemy, selekcjonujemy zdarzenia i procesy w otaczającym nas świecie. Kiedy szukamy odpowiedzi na pytanie, co to jest na przykład nuda warto sięgnąć do prac na temat mózgu, ponieważ w sposób bardziej jednoznaczny i udokumentowany empirycznie wskazują nam, jak przeżywamy czas i w jaki sposób powstaje uczucie nudy ${ }^{8}$. Nowe inspiracje metodologiczne, z których czerpać mogą i powinni historycy dziejów najnowszych nie różnią się jednak istotowo od tych, które będą przydatne dla wszystkich innych historyków. Wszyscy badacze dziejów powinni rozwijać umiejętności rozszerzonej konceptualizacji przedmiotu swoich badań. Powinni też poszukiwać inspiracji dla porządkowania chaosu informacji, którymi rozporządzają, a co za tym idzie - ćwiczyć się w selekcji i ocenie znaczenia zagadnień analizy, procedur poznawczych i własnej praktyki badawczej. Wiedząc lepiej (ale nie w sposób absolutny) jak ludzie pamiętają, jak opowiadają o zdarzeniach, rozumiejąc dystans, jaki oddziela świat przedstawiony w źródłach od wydarzenia i procesu, które na tej podstawie badamy i o którym opowiadamy, lepiej panujemy nad zwodzącym nas poczuciem pewności i pewnej (absolutnej) wiedzy. Takiej historyk nie ma i nie wynika to z jego złej czy dobrej woli - wynika to jedynie z tego, że poznajemy aspektowo i nie możemy sobie rościć prawa do poznania absolutnego. Poznanie jest pełne, ale tak jak każde, $w$ ramach określonego aspektu minionego świata - wielkiego nurtu stawania się dziejów.

W obecnej debacie, która toczy się w Polsce na temat dziejów najnowszych, na temat napięć pomiędzy pamięcią (racją) indywidualną, ksztaltów pamięci zbiorowej, winy, odpowiedzialności, polityki wstydu, czy też polityki dumy, za sprawę kluczową uważam podjęcie studium wymiaru aksjologicznego, etycznego i moralnego zarówno pracy historyków, jak też wydawanych przez nich ocen oraz badanej przez nich przeszłości. Zwrot etyczny nie jest w dziejach ostatnich kilkudziesięciu lat historiografii niczym nowym. Dawno już powstały koncepcje, które waloryzują słabszych, prześladowanych, zdominowanych, pozbawionych prawa do wyrażania siebie, świat zwierząt (i perspektywę patrzenia na przeszłość z ich punktu widzenia). Nie chodzi więc tutaj o postulat niekonwencjonalny, ale właściwie dobrze znany. Chodzi o przemyślenie i wypowiedzenie przekonań etycznych. Najpierw powinno to dotyczyć zasad związanych z postępowaniem historyków: co jest nieprzekraczalną normą etyczną w naszym zawodzie, gdzie i dlaczego sytuuje się nasza wrażliwość

8 E. Pöppel, Granice świadomości. O rzeczywistości i doznawaniu świata, Warszawa1989, s. 90 i n. 
moralna jako badaczy. Następnie powinno to dotyczyć zasad etycznych i moralnych badanych przez nich światów, bo przecież nie ma pod tym względem ani jednorodności ani spójności. Społeczny charakter świata ludzkiego sprawia, że systemy aksjologiczne są różne - powiązane ze sobą, ale różne. Warto je uczynić przedmiotem badania, a wiedzę o nich wykorzystywać $\mathrm{w}$ reprezentacji opowieści o przeszłości. I wreszcie trzeci poziom studium aksjologicznego: ujawnienie zasad, wedle których ocenia się przeszłość. Jeżeli ta ocena ma charakter teleologiczny (wartościujemy pozytywnie wszystko to, co zbliża nas do zakładanego celu tj. sytuacji, która powinna zaistnieć), w tym miejscu można dla uproszczenia powiedzieć, co zbliża badaną przez nas wspólnotę czy osobę do osiągnięcia większego dobra. Musimy jednak wyjaśnić, co za dobro uważamy; tego nie powinno się pozostawiać tylko intuicyjnym, niezwerbalizowanym i nieprzemyślanym przekonaniom.

Odpowiadając wreszcie na pytanie zawarte w tytule (Historia najnowsza - pomiędzy pewnościa a zwatpieniem?) pragnę powiedzieć, że ani absolutna pewność ani zwątpienie - badacze dziejów najnowszych powinni podążać Via media - zbliżając się raz do jednej, raz do drugiej skrajności, ale dążąc wytrwale, aby nie popaść w żadną z nich.

Koda: Historia przedstawiona w filmie Piknik pod Wiszacca Skała naprawdę się nie wydarzyła. Joan Lindsay, autorka książki, która była podstawą scenariusza, napisała w niej rozdział wyjaśniający co się stało z zaginionymi dziewczętami i ich nauczycielką. Wydawca książki usunął ten rozdział. Wyszedł on drukiem dopiero po śmierci autorki. $W$ książce, a potem w filmie, błędnie podano datę zdarzenia: Dzień św. Walentego 14 lutego 1900 roku przypadał na środę a nie na sobotę, jak jest podane i w książce, i w filmie. 